\title{
Fire System Analysis and Optimization of Suitable Fire Control System
}

\author{
"J. Stalin Durai , R. Vigneshwaran \\ Department of Mechanical Engineering,M.E. (Industrial Safety Engineering), Sri Sai Ram Institute of Technology, \\ Chennai, Tamil Nadu, India \\ *Corresponding author Email:sitp20is09@sairamtap.edu.in
}

\begin{abstract}
Fire is one of the major hazards which may occur due to natural or man-made causes. This report presents the importance of suitable fire systems in case of fire. In general, fires may be classified into five categories depending on the fuel that is burning. In recent times, there is an increase in incidence of fires in urban population due to very densely populated areas. The losses associated due to fires can be classified as loss to the life of structure, loss of human life and loss to property. Analysis of fire loads of different compartments and providing sufficient number of firefighting equipment's can help in reducing the severity of fires. The fire loads and fire densities were analyzed at some locations to determine the requirements of firefighting equipment's with suitable extinguishing agents. Fire risk assessment is the process of identifying the hazards present in the various places and the people who are at risk and evaluate and reduce the risk by discuss with the employees and taking corrective actions. The assessment activities are record and documented for the future purpose. This report includes study of various types of fire, fire extinguishers, calculation of fire load and selection of suitable fire system to reduce and control the fire accidents as per legal standards.

Keywords:Incident, fire system analysis, fire control system
\end{abstract}

\section{Introduction}

Fire is one of the major hazards in manufacturing company. The fire accident may occur natural or manmade. Every year, fires cause huge damage and loss of eco- nomy. A special fire hazard is caused by substances that are highly flammable which are likely to cause a very quick fire spreading. For most fires, water represents the ideal extinguishing agent. The fire protection system like Fire sprinklers and Suppression System utilize water, gas or clean agent by direct application onto flames and heat, which causes cooling of the combustion process and prevents ignition of adjacent combustibles. They are most effective during the fire's initial flame growth stage, while the fire is relatively easy to control. In such cases, conventional sprinkler systems may not be activated quickly enough to provide adequate protection. A suitable fire extinguishing media detect a fire particularly fast and cover the area with a source at the same time over all nozzles in the extinguishing area. This approach ensures that fires in rooms with flammable goods can be extinguished quickly and with minimum damage.

\section{Problem Identification}

By the survey, following highly flammable hazardous areas for fire are identified as: Chemical / Paint Storage yard, Substation, LPG yard, Cylinder storage area, Admin Building, Boiler area. I have classified the hazards into three categories as Low risk, Medium risk, and High risk according to their fire load density, existing control measures as per Legal requirements. By conducting Fire Safety Audit by using Fire Safety Audit Checklist the chemical storage / paint storage yard has major deviations in existing fire system in compare with other areas. The existing fire system consisting of smoke detector and manually operating DCP \& CO2 extinguishers onlyIf a fire broke out in the Storage yard its difficult to control because of the storage of chemicals above $25 \mathrm{KL}$, using manually operating extinguishing media's.

\section{Fire System / Fire Protection System}

The fire systems reduce damage to the building, expensive equipment, documents, and inventory. Fire suppression systems, smoke detectors, and sprinkler systems are all types of fire protection systems that help with fire detection and protecting building occupants and equipment. Active fire protection active fire protection means using a system that reacts in case of a fire. Examples of active fire protection include sprinkler systems, detectors and special hazard fire suppression system. Smoke detector a smoke detector is a device that senses smoke, typically as an indicator of fire. Commercial smoke detectors issue a signal to a fire alarm control panel as part of a fire alarm system, while household smoke detectors, also known as smoke alarms, generally issue an audible or visual alarm from the detector itself or several detectors if there are multiple smoke detectors interlinked. Objective the primary goal of this project work is to study the existing fire system present at the high hazardous area in the manufacturing industry. Based on the goal the following specific objectives are 
chosen for the study to identify the major fire hazard location in the company and prioritize them, to check the existing fire control system in the identified fire hazard location, to provide suitable fire control system.

\section{Selection of Fire Hazard Area Using Fra}

Depends on the fire risk assessment conducted in the industry, the results showing major deviations in the chemical $\&$ paint storage yard due to that choosing the storage yard for fire load calculation \& reviewing the existing fire system as per is2189:2008-selection, installation and maintenance of automatic fire detection and alarm system-code of practice,is15105:2002-design and installation of fixed automatic sprinkler fire extinguishing systems -code of practice. fire risk assessment at industry the fire risk assessment was conducted through fire safety audit checklist to find out the major deviations present in the hazardous area $\&$ helps to prioritize them. The following fire audit checklist shown below was used to perform the fire risk assessment in the hazardous area. Methods for fire load calculation estimation of combustible material of a building can be determined by three methods. direct measurement of mass, with conversion based on the net heat of combustion direct measurement of volume (with conversion based on a combination of density and net heat of combustion) energy release measurement by calorimetric of an item sufficiently.

\section{Fire Load Calculation}

Fire load density is defined as the amount of heat liberated from a combustible material per square meter in floor area. Fire load is to determine the severity and building up of fire. Fire load is a useful in determining the growth and severity of fires.The mass of the material is calculated in $\mathrm{kg}$. The calculated mass is multiplied by its calorific value in $\mathrm{MJ} / \mathrm{kg}$ to get fire load. The calculated valve is then divided by area of the floor to give fire load density.

$$
q_{c}=\frac{\sum m_{v} H_{v}}{A_{f}}
$$

Where,

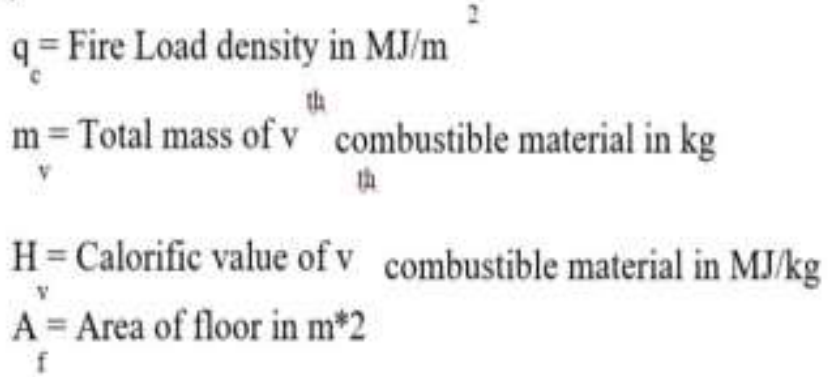

\section{Calorific Values}

The mass of combustible products is calculated by digital weight meter. If the mass is unknown, volume of the material is calculated in $\mathrm{m} 3$ and the calculated volume is multiplied by density of the material in $\mathrm{kg} / \mathrm{m} 3$. So the formula for calculating mass is given as,

$$
\text { Mass }=\text { Volume } * \text { Density }
$$

\section{Conclusion}

Through fire accidents are likely to occur in combustible and highly flammable atmospheres. Early control of fire at initial stage helps to prevent loss of life, environment or property damage. By implementing suitable Fire system at work place helps to reduce the impact of fire and also prevent the fire at initial stage. In this project, the risk assessment should be conducted at the workplace in order to change manually operating extinguishing media to prevent the fire in early stage and protect the task force team from direct exposure to fire. If fire occurs, the additional control measure given helps to extinguish the fire at initial stage \& prevent the loss of property, loss of life and environmental impact. 


\section{References}

[1]. Dr.Khalid Moinuddin, (2019), "Reliability of Fire Sprinkler System", Victoria University, Melbourne, Australia.

[2]. Terry McDermott (2017), "Efficiency and Effectiveness of Sprinkler Systems in the United Kingdom: An Analysis from Fire Service Data", Optimal Economics NFSN.

[3]. Peter Raia, Michael J. Gollner (2014), "Literature Review on Hybrid Fire Suppression Systems", Fire Protection Research Foundation, University of Maryland.

[4]. M. Lakkonen, D. Sprakel and A. Feltmann (2014), "Comparison of Deluge and Water Mist Systems from A Performance and Practical Point of View”, 7th International Conference „Tunnel Safety and Ventilation“ 2014, Graz.

[5]. Zhigang Liu and Andrew K. Kim (2014), "A Review of the Research and Application of Water Mist Fire Suppression Systems - Fundamental Studies”, Journal of Fire Protection Engineering, v. 10, no.3, 2000, pp. 3250.

[6]. Len Garis and Dr. Joseph Clare (2013), "Sprinkler Systems and Residential Structure Fires Exploring the Impact of Sprinklers for Life Safety and Fire Spread", Research University of the Fraser Valley.

[7]. Kevin Frank, Neil Gravestock, Michael Spear point and Charles Fleischmann (2013), “A review of sprinkler system effectiveness studies", Franketal. FireScienceReviews2013, 2:6.

[8]. Dr.S.M.Tauseef (2013), "Numerical study on effectiveness of water mist in interacting pool fire suppression using Fire Dynamics Simulator”, Summer Research Fellowship Programme of India's Science Academies.

[9]. Cameron, K.H. (1994), “An international company's approach to managing major incidents”, Disaster Prevention and Management, Vol. 3 No. 2.

[10]. Carpenter, M.A. (2002), "The implications of strategy and social context for the relationship between top management team heterogeneity and firm performance", Strategic Management Journal, Vol. 23 No. 3, pp. 27584.

[11]. Fitzsimmons, J.A. (1973), “A methodology for emergency ambulance deployment”, Management Science, Vol. 19 No. 6, pp. 627-36.

[12]. Ford, J.K. and Schmidt, A.M. (2000), "Emergency response training: strategies for enhancing real-world performance", Journal of Hazardous Materials, Vol. 75, pp. 195-215.

[13]. Duijim, N.J., (2009) "Safety-barrier diagrams as a safety management tool. Reliability Engineering and System Safety" pp 94, 332-341.

[14]. De Dianous, V.,Fievez, C., (2006), “ARAMIS project: a more explicit demonstration of risk control through the use of bow-tie diagrams and the evaluation of safety barrier performance" Journal of Hazardous Materials.130, 2033. 